\title{
Price Bubbles in the Real Estate Markets - Analysis and Prediction
}

\author{
PAWEŁ DEC \\ Institute of Corporate Finance and Investment \\ SGH Warsaw School of Economics \\ Al. Niepodleglosci 162, 02-554 Warszawa, Poland \\ POLAND \\ GABRIEL GŁÓWKA \\ Institute of Corporate Finance and Investment \\ SGH Warsaw School of Economics \\ Al. Niepodleglosci 162, 02-554 Warszawa, Poland \\ POLAND \\ PIOTR MASIUKIEWICZ \\ Scientific Society of Praxeology \\ ul. Madalińskiego 31/33, 02-554 Warszawa, Poland \\ POLAND
}

\begin{abstract}
The article concerns the issue of price bubbles on the markets, with particular emphasis on the specificity of the real estate market. Up till now, more than a decade after the subprime crisis, there is no accurate enough method to predict price movements, their culmination and, eventually, the burst of price and speculative bubbles on the markets. Hence, the main goal of the article is to present the possibility of early detection of price bubbles and their consequences from the point of view of the surveyed managers. The following research hypothesis was verified: price bubbles on the real estate market cannot be excluded, therefore constant monitoring and predictive analytics of this market are needed. In addition to standard research methods (desk research or statistical analysis), the authors conducted their own survey on a group of randomly selected managers from Portugal and Poland in the context of their attitude to crises and price bubbles. The obtained results allowed us to conclude that managers in both analysed countries are different relating the effects of price bubbles to the activities of their own companies but are similar (about $40 \%$ of respondents) expecting quick detection and deactivation of emerging bubbles by the government or by central bank. Nearly $40 \%$ of Polish and Portuguese managers claimed that the consequences of crises must include an increased responsibility of managers for their decisions, especially those leading to failures.
\end{abstract}

Key-Words: price bubble, real estate market, crisis, managers

Received: June 21, 2021. Revised: December 16, 2021. Accepted: January 14, 2022. Published: January 16, 2022.

\section{Introduction}

The problems of prediction and socio-economic consequences of a price bubble on the housing market are an important area of research dealing with the volatility of creation factors and shock events. The international subprime crisis of 20072009, when the real estate price bubble burst, was an example of dramatic social and economic consequences. The time of acquisition of information about the risk of a price bubble is crucial for two reasons - the earlier the bubble can be detected, the easier it is to avoid its growth; the ordinary economic policy tools become less effective when the housing market enters the phase of boom. The authors primarily aim to present a possibility of early detection of price bubbles and their consequences from the point of view of the surveyed managers. The verified hypothesis is that price bubbles on the real estate market cannot be excluded, which is why constant monitoring and predictive analytics of this market are indispensable. It should be noted that the authors reject the hypothesis of the efficiency of financial markets and consider the irrationality of the real estate market investors possible. The research methods used in this publication include analysis of domestic and 
foreign literature, CAVI research as well as statistical analysis of the obtained results.

\section{Problem Formulation}

Observations of the processes taking place in the modern economy show that one of the basic manifestations of crisis shocks is the fluctuation of asset prices on every market. Hence, numerous studies on the subject $[1,2,3,4,5]$. The key issue regarding the asset market is the problem of the convergence of asset prices with their fundamental value $[6,7,8,9]$. Significant disproportions between the price and value of assets usually lead to the emergence of a phenomenon on the market, which is referred to as price bubble. This term very aptly reflects the impermanence and instability of this process. A price bubble grows when the market for a specific type of asset rises in the current prices of assets above their fundamental values. The fundamental value of an asset is its value resulting from the usefulness of the asset, expressed by the price level in the conditions of equilibrium. A price bubble on the asset market means a deviation from a dynamic equilibrium of the market, which results from its very character [10].

\subsection{Theoretical Aspects of the Development of Price Bubbles on the Markets}

The phenomena of growing and bursting of price bubbles on asset markets are becoming a direct cause of disturbances in the stability of economies. It is based on at least two reasons. The first is that excessively high asset prices do not properly fulfil the informative function of prices, which contributes to the inadequate allocation of resources, since too many of them are allocated in assets characterised by much stronger dynamics of price growth than implied by fundamental factors. Secondly, the burst of the asset price bubble most often makes significant losses in the financial sector, causing at the same time a threat to financial stability and a deep collapse in economic growth $[11,12]$.

However, it should be emphasised that not every increase in asset prices must mean a price bubble growth. A progressive increase in asset prices may be determined by fundamental factors. An asset market bubble occurs when an increase in asset prices is not based on fundamental factors. P. Garber, characterising this phenomenon, defines it as "part of asset price movement that is unexplainable based on what we call fundamentals" [13]. And J. Stiglitz states that "if the reason that the price is high today is only because investors believe that the selling price will be high tomorrow-when "fundamental" factors do not seem to justify such a price - then a bubble exists." [14]. On the other hand, according to Mr Kindleberger, a price bubble is "a sharp rise in price of an asset or a range of assets in a continuous process, with the initial rise generating expectations of further rises and attracting new buyers" [15].

The essence of the price bubble is therefore manifested in the behaviour of asset market players, consisting in undertaking transactions in overvalued assets. Thus, it is important to answer the question of what makes investors willing to accept asset prices on the market that are significantly different from their fundamental value. To some extent, one can try to answer this question on the basis of the models of asset market price bubbles presented in the literature. $[10,16]$. According to the research assumptions made to analyse speculative bubbles on asset markets, we may talk about the rationality of speculation and then we have to do with a rational bubble. Then, investors rationally anticipate the expected value of dividends to be discounted and prices to rise as a result of speculative behaviour, and they predict the probability of a price bubble burst within a specific period of time. There may also be bubbles on the asset market described as irrational [17]. In this case, investors make decisions in an irrational way, on non-economic grounds, for example as an element of herd behaviour. Eventually, information bubbles may appear on asset markets due to asymmetry or misinterpretation of information [17]. The reason for the formation of a price bubble is then that asset prices do not discount all information or there is some overinterpretation of it. The observation of real estate markets shows that there are cyclical fluctuations in the level of prices and the number of buildings put into use. These fluctuations may be determined by fundamental factors, but they may also come as a result of various types of external shocks [18].

Price bubbles of various character may appear on many kinds of asset markets; the phenomenon is not confined to financial markets only. Increasingly, it also applies to real estate markets. A considerable significance of the real estate market in the modern economy becomes an important motivation for a deeper analysis of the processes taking place on it, also in this area. A real estate market is subject to fluctuations in activity and changes in the dynamics of development, which is a natural phenomenon in the market economy. The most important manifestation of its cyclical development is primarily changes in the price level $[19,20,21]$. Price fluctuations on the real estate market have an important impact on the way it operates and on the 
related sectors of economy. First of all, they significantly affect the condition and stability of the financial sector, the financial results of large groups of investors, and consequently the economic situation in the entire economy [22, 23].

\subsection{Theoretical Aspects of the Development of Price Bubbles on the Markets}

The phenomena of growing and bursting of price bubbles on asset markets are becoming a direct cause of disturbances in the stability of economies. It is based on at least two reasons. The first is that excessively high asset prices

According to M. Friedman [24], scientific theories cannot be judged by the truth of their assumptions, but by their usefulness for making accurate predictions. For crisis prevention, it is important to monitor the market, including price dynamics [23, 25]. Typical instruments for measuring price changes include analysis of price dynamics and dispersion, analysis of correlation with incomes (e.g., households), analysis of the price scissors opening and fundamental value of the asset, etc. A relatively new method of assessing the risk related to price movements is the use of stress tests. For example, some central banks (such as the National Bank of Poland) conduct stress tests in the area of bank resistance to the deterioration of the quality of housing loans and the decline in real estate prices $[26,27]$. To this end, estimates are made of how a decline in real estate prices could affect bank sensitivity to the deterioration of the loan portfolio quality. The results of the test showed a high sensitivity of banks to the deterioration of the quality of housing loans. The usefulness of stress tests has also been confirmed by independent researchers $[28,29]$.

In theory and practice, the methods of price analysis on the housing market are most comprehensively developed. Generally known measures of imbalance on this market include the following indicators [30]:

- the ratio of the average price of one sqm of an apartment to the average annual household income $(\mathrm{P} / \mathrm{I}$ ratio), informing about the number of years necessary to buy an apartment,

- the cost and profit structure of the developer with regard to the construction of an apartment on a local market (national, regional),

- price dispersion index against a competitive country or region and price dispersion index between bear market and bull market,

- comparative analysis on the basis of rent, i.e., comparison of the market price of the apartment with its price determined by discounted income from rent (discounting the stream of future rents and the resale value of the apartment); a significant positive difference is a signal about the expectation of price increases included in the market price,

- analysis of the ratio of the cost of possessing an apartment to the cost of its rental ( $\mathrm{P} / \mathrm{R}$ ratio), where the cost of renting may be close to the amount of rent, and the cost of ownership is increased by the cost of interest and commission on the housing loan (renting an apartment as a substitute for its ownership),

- examination of changes in the Case-Shiller house price index (USA).

However, these indicators may not be reliable when rental prices and rents begin to rise above average, along with housing prices rise in the short term. If apartment sellers make above-average profits from apartment trading on an annual basis (or on average over a period of several years), this is the first sign of a growing price bubble. A separate issue is the analysis of arbitrage between capital investment submarkets, e.g., the relationship between price changes in the market of bank deposits, gold, securities, and real estate [31].

Predictive analytics is the next step in price bubble detection, following descriptive and diagnostic analytics. In the case of descriptive and diagnostic analytics, it is the historical data that are primarily used to explain events in the past. Predictive analytics goes beyond this framework; i.e., it uses data to predict the future. Thanks to this, consulting companies or financial directors are able to base their decisions on real numbers, and not only on their own intuition [32]. The basic role of predictive analytics in planning and predicting the future is indicated, for example, by J. Waupsh [33], S. Łobejko [34], Lepenioti et al. [35].

Econometric models used in prediction can be divided by goal:

- classification - discrete target (e.g., decision trees, logistic regression),

- approximation - continuous target (e.g., linear regression, neural networks),

- association - co-occurrence of values (e.g., Apriori algorithm, associative networks),

- segmentation - division into segments (e.g., kmeans algorithm, Kohonen networks).

Unfortunately, most of their component measures were quite often based on historical data 
and old research. Today, the availability of basic tools for conducting the prediction process allows for advanced analytics:

- data mart (thematic data warehouse) - a logically separated range of data stored in the organisation, focusing on one topic, e.g., sales support, created to support decisions on this subject.

- data warehouse - a central repository integrating data collected and produced by various units of the entity, as a result of various business processes.

- ETL (Extract, Transform, Load) - a process in a data warehouse responsible for downloading data from a single source, transforming them to fit the processes in which they will be applied, and then loading them into the target database.

- data quality verification applications - processes and techniques related to ensuring the reliability of data and the efficiency of their use. Data are of high quality if they reliably reflect the business processes to which they refer and fit the intended uses in operation activities, decision-making and planning.

- tools for predicting company bankruptcies (e.g., discriminatory, logit, probit, neural networks, etc.).

Another method that can be useful when forecasting bubbles is foresight methods. They are divided into heuristic and econometric, quantitative, and qualitative (descriptive). Below are some of the most characteristic of these methods that can be used in international, national, corporate as well as regional research. The foresight methodology includes a number of predictive analytics methods (Table 1).

Table 1. Foresight methods

\begin{tabular}{|c|c|c|c|}
\hline No. & Heuristic methods & No. & $\begin{array}{l}\text { Econometric } \\
\text { methods }\end{array}$ \\
\hline 1 & Delphi method & 1 & Trend analysis \\
\hline 2 & SWOT analysis & & - Structural analysis \\
\hline 3 & PEST Analysis & & of trends \\
\hline 4 & Prioritization & & - Conditional trend \\
\hline & $\begin{array}{l}\text { (brainstorming, } \\
\text { others) }\end{array}$ & 2 & $\begin{array}{l}\text { analysis } \\
\text { Building scenarios }\end{array}$ \\
\hline 5 & Modified workshop & 3 & Anticipative \\
\hline 6 & Exnert nanels & 4 & Discrete Fven \\
\hline & specialist - modified & 5 & $\begin{array}{l}\text { Systems } \\
\text { S }\end{array}$ \\
\hline 7 & Social Consultation & & - bankruptcy \\
\hline 8 & Decision tree & & prediction models \\
\hline 9 & Bayesian model & 6 & Modeling of system \\
\hline 10 & Others & & $\begin{array}{l}\text { dynamics } \\
\text { Stress tests }\end{array}$ \\
\hline
\end{tabular}

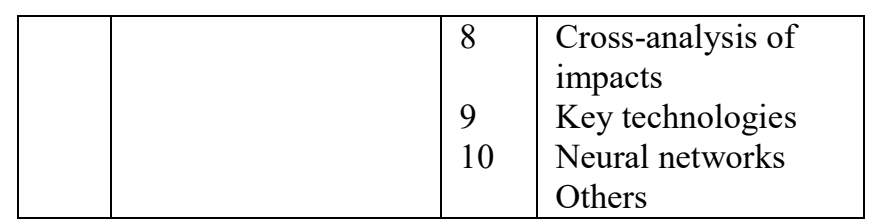

Source: [32].

A. Czerniak and B. Witkowski [36] presented an early warning econometric model (EWS) against price bubbles on the housing market in 18 OECD developed countries. The explanatory variables for this model were selected with the use of the Bayesian Averaging (BMA) method from an extensive set of potential determinants of price bubbles on housing markets, i.e., economic, demographic, institutional and socio-cultural. The statistics used by the authors show that the EWS model constructed in this way shows significantly better prognostic properties than the models used so far in the literature. This result was obtained due to econometric modelling variables illustrating the institutional and socio-cultural conditions of the functioning of the housing market; they have as a rule been ignored in research so far.

Simple methods of extrapolation and interpolation of price trends are hardly useful in forecasting price bubbles, because they do not account for extraordinary shock phenomena. Instead, the PEST factor analysis may be useful for forecasting price changes, as shown in Table 2.

Table 2. Factor analysis of housing prices - PEST

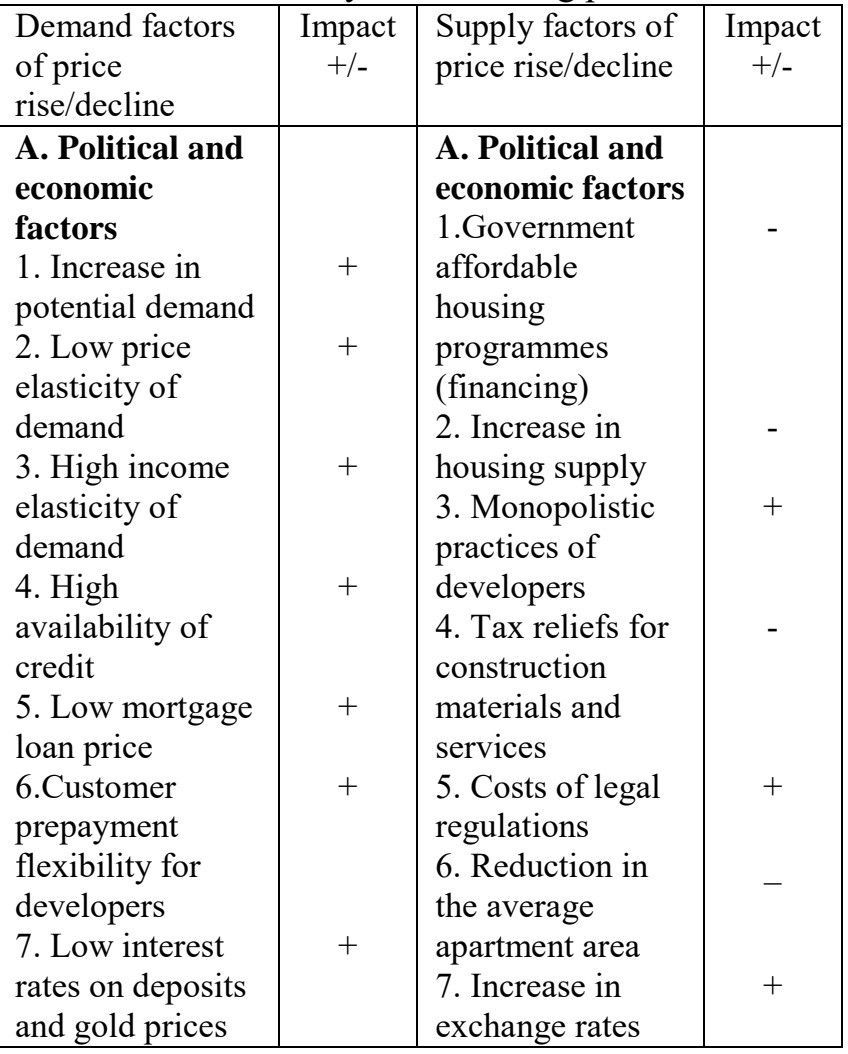




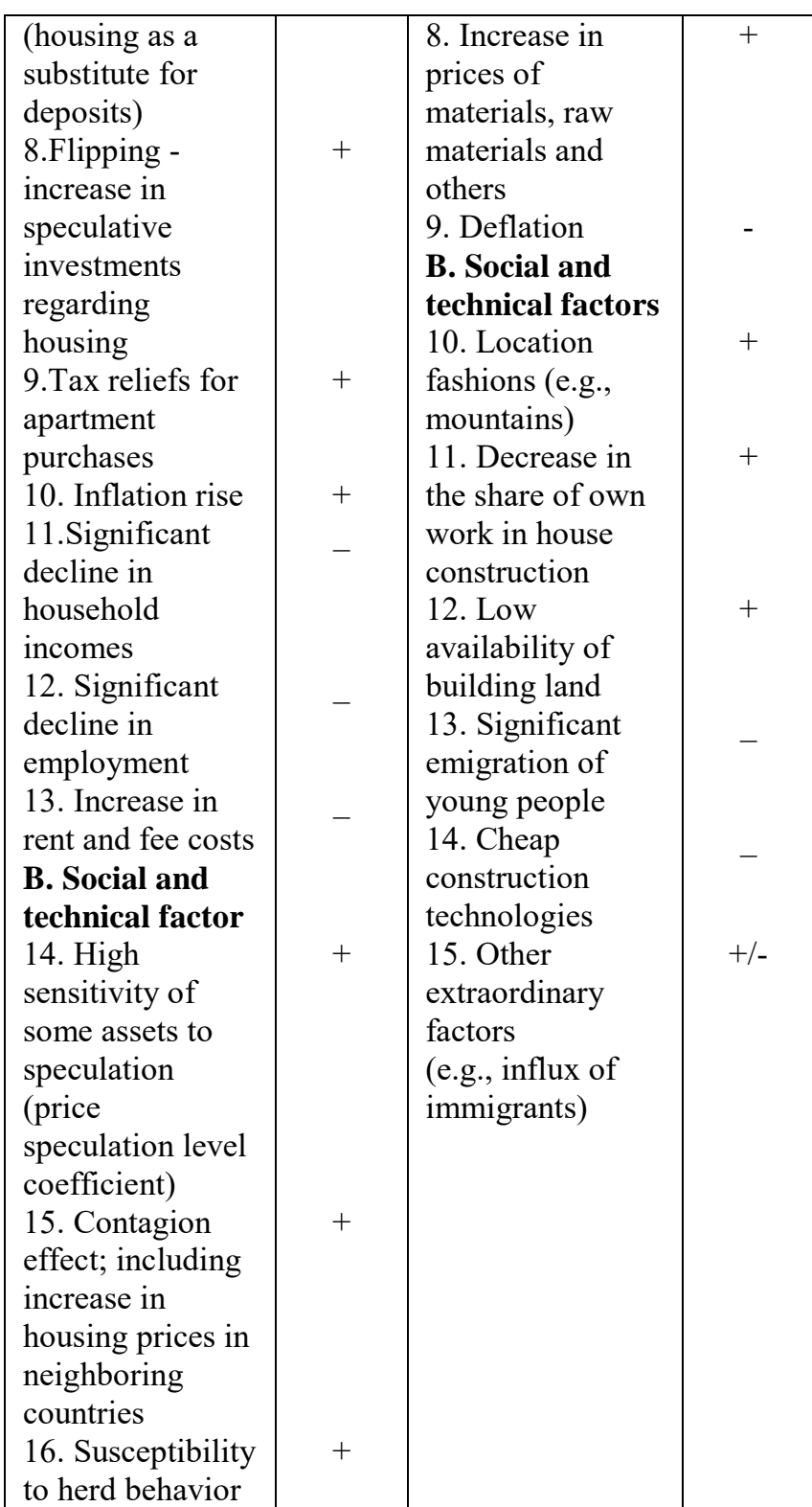

Source: Authors' own work.

Usefulness of the PEST analysis when forecasting home prices, as it provides more additional information than a simple extrapolation of the current development trends and changes. This, in turn, may contribute to faster detection of price bubbles in such a market. The current possibilities of using modern technologies, machine learning and artificial intelligence create additional value in this area.

One of the important channels of contagion of the crisis on an international scale was the behavioural channel, creating price bubbles [30, 37]. Distortions of perception of reality through heuristics and the so-called mental accounting (the work of Khaneman and Tversky) when making decisions by investors and clients must be taken into account in anti-crisis activities. The basic methods of such research are demoscopic methods. The lack of broader analyses, the need to use psychological knowledge, a small spectrum of socio-psychological tools for deactivating bubbles and few studies in this area justify broader research of behavioural factors. However, it goes beyond the scope of this article [30].

To recapitulate, no economic model is able to account for all the events, because, for example, beyond the horizon of forecasts, there is a terra incognita of cognition, i.e., what we do not know that we do not know. A pandemic or another extreme event that is very unlikely to occur, but when it occurs, it has a significant impact on reality (it is referred to as a "black swan"). The disadvantage of the models used is the risk of identifying, as a price bubble, those boom periods on the housing market in which investors did not succumb to irrational enthusiasm [38]. N. Taleb [39] observed that the knowledge contained in models may be meaningless when confronted with an extreme phenomenon (i.e., a factor of bubble creation). According to the authors, black swans may be an increasingly common phenomenon in world economies. Hence the need for a greater opportunity to explore the uncertain and volatile environment of enterprises in order to minimize the potential negative effects of such non-obvious events.

\section{Problem Solution}

The research was conducted in November 2019 on a random group of 200 managers (CEOs, board members, CFOs, business owners) from Poland and Portugal (100 people from each country). Computer-aided interviews (CAVI) were conducted in Poland by renowned research company Indicator, and in Portugal in cooperation with a local partner company. The ordering, interpretation and evaluation of the research results were completed by the authors of this article.

It is very difficult to predict the occurrence of further economic crises, the crowning example of which was the subprime credit crunch of 2007/2008; and recently also typical health phenomena, such as the coronavirus pandemic. Meanwhile, as history shows, they have a huge impact on the functioning of the vast majority of companies. Hence, our first question was about the lessons resulting from the experienced crises as well as the consequences managers see for themselves in connection with them (Figure 1). 


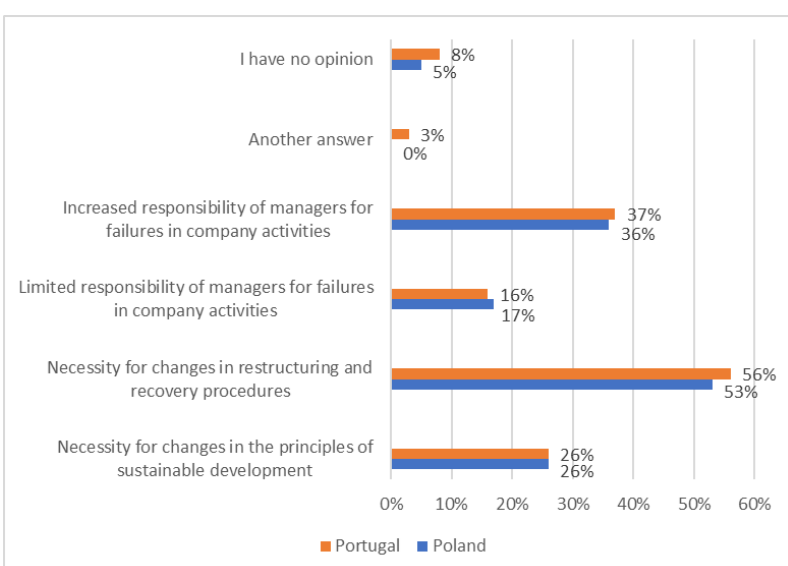

Fig. 1: Contribution of economic crises (economic, financial, real estate) to various types of situations. Source: Authors' own study.

Portuguese (56\%) and Polish (53\%) managers reported that the occurrence of economic crises (economic, financial, real estate) contributes to the necessity for changes in restructuring and recovery procedures. Therefore, it can be seen how many of them must have experienced difficulties when going through recent crises (probably local recessionary phenomena as well) so that now they can see the need for legislative corrections in this area. More than a third of the responses (in Poland $-36 \%$, in Portugal 37\%) concerned increased responsibility of managers for failures emerging in the company operations. Thus, the problem of the guilt of company managers for their business failures and their proper subsequent settlement is conspicuous. Although $16 \%$ of Portuguese and 17\% of Polish managers indicated the opposite direction of action in favour of limiting the responsibility of managers for possible failures, exactly due to the existing crises, i.e., there may be situations that cannot be predicted and it is difficult to blame the managers for everything. Such reasoning may be well founded with regard, for example, to the current pandemic, where many actions of state authorities had an adverse impact on the company operations and increased the risk of bankruptcy. Eventually, a fairly large group of respondents $(26 \%$ each in either country) indicated that the lesson from the existing crises in the world should result in changes in the principles of sustainable development. Further research on specific types of crises and their impact on changes in managerial behavior definitely requires a longer research perspective.

Economic crises, changes in people's attitudes, new trends and phenomena in societies and economies (e.g., sharing economy) raise a question whether individual states or organised groups of states should conduct policies aimed at increasing regulations and procedures or rather limit and deregulate economies; should we then expect deeper and broader actions, such as deactivating speculative bubbles? The research indicates that $46 \%$ of Polish and $36 \%$ of Portuguese managers claim that they are a threat to the activities of any company. The opposite opinion, i.e., that they do not affect the activities of all companies, was expressed by $35 \%$ of respondents in Poland and $48 \%$ in Portugal. Thus, there is a fundamental difference between the two countries, Polish managers are more cautious and feel more respect for such phenomena than their Portuguese colleagues. Although the attitude of both groups to their deactivation is very similar. In Portugal, 37\% of respondents, and in Poland, 36\% believe that speculative bubbles should be quickly and efficiently deactivated by relevant state institutions in accordance with the implemented economic and monetary policies. However, $27 \%$ of managers in Poland think that there is no need for the state to deactivate them in order not to interfere with the free market (for comparison, in Portugal there were $17 \%$ of such responses).

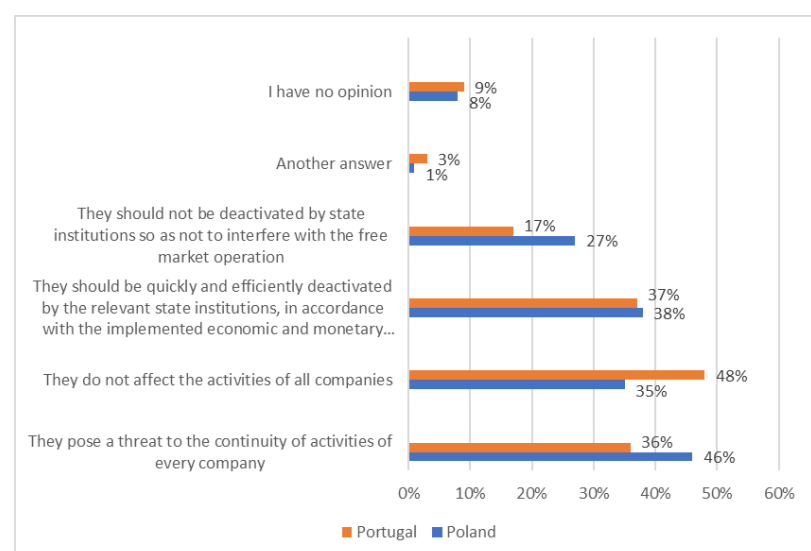

Fig. 2: Price bubbles in the economy, including the real estate market.

Source: Authors' own study.

The attitude of managers to the threats resulting from the emerging speculative bubbles and the potential direction of activities in this area shows the need for the state to be present in this area and to implement appropriate measures. So, state institutions can be expected not only to act as free market guardians, but also firm animators and initiators of specific actions. 


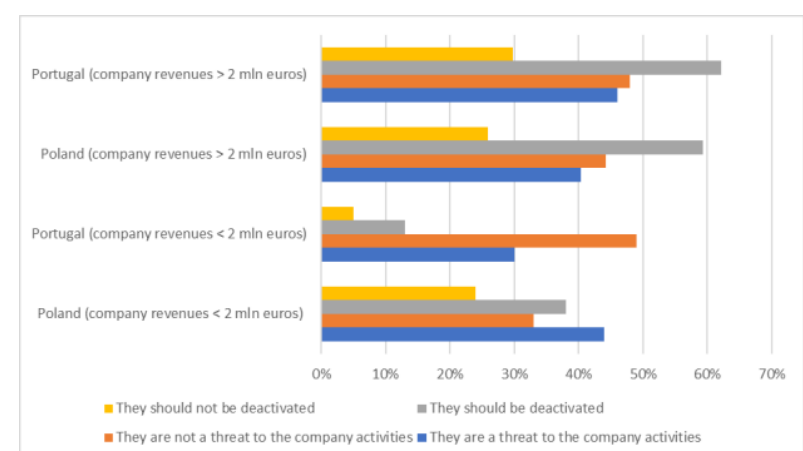

Fig. 3: Price bubbles - threat and deactivation determined by the size of company revenues.

Source: Authors' own study.

The authors also decided to examine in detail how managers, depending on the revenues obtained by their companies, approach threats and possible interventions in the area of price bubbles (Figure 3). Thus, $48 \%$ of Portuguese managers in companies with revenues above 2 million euros said that price bubbles do not pose a threat to the company activities, which is comparable to companies with revenues below 2 million $-49 \%$. The situation is slightly different in Poland, where in companies with revenues up to 2 million euros, according to $44 \%$ of managers price bubbles pose a threat to the company activities (33\% indicated otherwise), 40\% of respondents from entities with higher revenues were of a similar opinion, and $44 \%$ of managers did not consider them a threat to the activities of the company they manage. These answers are interesting when we compare them with the question about the need to deactivate price bubbles through interventions (made e.g., by the government or central bank). At that time, both in Poland and Portugal, regardless of the group of companies with specific revenue volumes, respondents pointed to the necessity for the price bubble deactivation. Strong supporters of deactivation of price bubbles were managers in companies with revenues above 2 million euros, in Portugal there were as many as $62 \%$ of them, while in Poland $59 \%$. It is possible then to explain no fear on the part of managers of speculative bubbles, as they expect a reaction from the government in this respect. This determines the need to develop tools for early forecasting and detection of potential price bubbles in the economy, especially those on the real estate market, the observation of which seems to be less complex than the phenomena referred to as black swans
Table 3. Statistical test results - t-test and Chi squared

\begin{tabular}{|l|c|c|}
\hline \multirow{2}{*}{} & \multicolumn{2}{|c|}{ Question 1 } \\
\cline { 2 - 3 } & t-test & p-value \\
\hline a1 & $-0,8605$ & 0,3895 \\
\hline a2 & $-1,7452$ & 0,081 \\
\hline a3 & $-0,1469$ & 0,8832 \\
\hline a4 & 0,195 & 0,849 \\
\hline a5 & $-0,426$ & 0,670 \\
\hline a6 & 0 & 1 \\
\hline & \multicolumn{2}{|c|}{ Question 2 } \\
\cline { 2 - 3 } & t-test & p-value \\
\hline a1 & $-0,2536$ & 0,7998 \\
\hline a2 & $-1,0102$ & 0,3124 \\
\hline a3 & 1,707 & 0,0878 \\
\hline a4 & 0,1461 & 0,8839 \\
\hline a5 & $-1,8656$ & 0,0621 \\
\hline a6 & 1,4377 & 0,1505 \\
\hline & \multicolumn{2}{|c|}{ Question 3 } \\
\cline { 2 - 3 } & Chi square & p-value \\
\hline a1 & 2,4439 & 0,655 \\
\hline a2 & 5,4177 & 0,247 \\
\hline a3 & 4,1681 & 0,384 \\
\hline a4 & 5,440 & 0,245 \\
\hline
\end{tabular}

Source: Authors' own work.

The statistical tests of the obtained results of the survey of managers in Poland and Portugal showed no grounds for rejecting the hypothesis about differences in the answers received (a1, a2, etc.) in the case of a question about crises (Question 1) or strictly price bubbles (Question 2). Therefore, it seems advisable to expand the research sample in the future to other countries, which on the one hand may provide valuable new results, but on the other hand, requires significant financial outlays for such research. Using the chi-square test for the case of the data from the third question, it was found that there was no reason to reject the hypothesis that the variables were independent. Therefore, the key goal seems to be to obtain results in this area from other countries and even continents, as the human factor may play a decisive role here.

\section{Discussion}

Our research shows that economic crises may lead to increased responsibility of managers for potential business failures, which was confirmed by the Covid-19 pandemic [40]. In the case of upcoming crises, it is still very important to study the causes of price bubbles (especially those on the real estate market, which are often the main trigger for the following economic crises). Many determinants of 
price bubbles and the related processes leading to crises have not yet been fully explained, and an appropriate time horizon is also necessary for this sort of research [41]. Moreover, each case of the phenomenon of price bubble on the real estate market seems to be different to a certain extent and has its own specificity. Therefore, according to the authors, it is difficult to fully agree with $\mathrm{J}$. Brzezicka [42], proposing a new typology of price bubbles, because they are constantly changing and their causes may be unexpected. The observation of real estate markets shows that these processes take place differently in every country as real estate markets, despite the progressing processes of globalisation, still largely retain their local and national character.

It is related to the conducted economic policy, including housing policy in every country, different real estate registration systems as well as diversity of legal systems with regard to real estate. The degree of development of the banking system and capital market are also important. And there is also a question here whether we can study the phenomenon of price bubbles with one method in different cities/countries as proposed by $\mathrm{S}$. Oh, $\mathrm{H}$. $\mathrm{Ku}$, D. Jun, [43], or try to use methods that account for the local specificity of the market (as the PEST method suggested by us). Experience also shows that in the case of the real estate market, we can generally talk about several groups of basic factors which, when overlapping each other, cause cycles and crises on this market $[44,45]$. The first of these is related to the structural feature of the real estate market, i.e., relatively rapid changes in demand, which, with a rigid supply reacting with a significant delay, cause an increase in prices [46]. And this triggers adjustment processes on the market, which after a certain period of time lead to increased supply of real estate.

An important problem, however, is that this supply usually appears when the demand on the market begins to fade, which means that increased supply often turns out to be too large. It manifests a certain specificity of the mechanism of price bubbles in the real estate market in relation to other types of markets, such as the financial asset market, where the process of adjusting demand and supply is much shorter due to the possibility of a relatively fast reaction of the supply of this type of asset. Secondly, speculative factors play an important role in the level of price fluctuations on the real estate market, the source of which is the widespread expectation of a further increase in prices. This belief motivates speculative purchases, which leads to increased demand and a growth in prices becomes a fact. Thus, a self-driven mechanism of price growth, price expectations and demand may be launched. It is facilitated by a clearly changing, for some time now, character of flats as goods, increasingly perceived as capital goods [47]. Therefore, the share of real estate purchased f9r investment purposes, also speculative is growing, both by natural persons and more and more often by investment funds. The effect of this mechanism is, as a rule, the detachment of prices from the economic reality and emergence of a price bubble on the real estate market. It should be emphasised, however, that in the case of the real estate market, there is an extremely important role in the formation of price bubbles played by the banking system, which through an excessively liberal way of lending can finance these dynamic price increases [48]. Here, too, a question arises as to whether our research results, indicating the expectation on the part of managers of an active role of the state in deactivating price bubbles, will be confirmed by the implemented policies, or whether the aspect of an early detection of price bubbles will still dominate [49]. Even more so because, as J.P. Rodrigue [50] pointed out, speculative bubbles have four phases, i.e., hidden, conscious, phase of mania and collapse (although there are, of course, other approaches to this problem - [51]). In the first of them, there is a situation in which people who know how to invest perfectly, begin to buy a hitherto unknown product, which, nevertheless, has great potential (the hope is growing) and in the future may bring them a large profit [50].

Then, along with the demand for it, its price also increases, and the product becomes more and more popular (desirable). This situation may occur especially in countries with significant tourist values [52]. In the next phase, there is a situation in which the investor world is already convinced that it is good to invest in this specific asset. The price of the asset is definitely higher than in the first phase, but still attractive and good to invest in. Demand is growing more and more; the price continues to rise even more until the first sell-off (bear trap) occurs. The third phase is the herd behaviour (mania) - in which even an average saver knows that it is worth investing in such a product, even if you have to pledge your own house or excessively borrow. Consumers go on thinking that the price of the asset is still attractive, which is deceptive, because a real profit could be expected by those who decided to buy in the first phase. Eventually, prices reach their apogee, and the market quickly approaches a crash i.e., the fourth phase occurs. In fact, some time ago, J. Stiglitz [53] emphasised that the problem of the 
real estate bubble should be approached not as an accidental market error, but as a consequence of bad legislation and inappropriate economic signals spread around the world. Currently, what can definitely be added to this is the black swan factor, i.e., the Covid-19 pandemic [54]. The example of Poland shows that in the first months of 2020, it was predicted that the following months would present a range of dynamics of property values between $-5 \%$ and $+5 \%$ (year on year, in transaction prices). It was to result from, for example, the further development of flipping in Poland, which has already established its position and covers a significant part of the secondary market of apartments in the largest cities.

According to data published by the National Bank of Poland in the first quarter of 2021, on the largest housing submarkets, the average transaction price of an apartment bought from a developer was $7.7 \%$ higher than a year before, and in the second quarter of 2021 this increase shot up even more - up to $10 \%$. This growth group includes the major Polish cities: Gdańsk, Gdynia, Kraków, Łódź, Poznań, Warsaw and Wrocław. In the case of secondary housing, price increases were lower. Prices per 1 meter of used premises increased at the beginning of 2021 by $6.5 \%$ more than a year before. Such an increase in housing prices was affected by many factors [55]. A large increase in COVID-19 cases in Europe and the protective measures taken by every country caused negative economic effects which may also affect the real estate market in the area of supply as well as prices.

The pandemic, contrary to last year's fear, did not overturned the housing market; although the price increase was clear. In addition, there is still a high housing demand and the supply is limited. A significant positive impact on demand was exerted by very low interest rates, traditions of thesaurisation of savings in real estate, low propensity to risk (e.g., to invest in the capital market), easier credit terms, and also high potential demand of young families. According to the data of the key player on the credit information market in Poland - BIK, the value of housing loans granted in the first quarter of 2021 amounted to about PLN 26 billion. Importantly, developers could build even more apartments, but to some extent it is hindered, apart from constantly rising land prices, prolonged administrative procedures, no attractive plots put up for sale, as well as financing barriers. This is confirmed by the fact that the number of vacant plots in Warsaw is lower than a few years ago, and most new investments are made in areas far from the centre; a quickly developing public transport network is their advantage. There are also transactions for the purchase of post-industrial areas by developers (such as the purchase of 62 hectares by one of such companies in August 2021. It will be possible to build up to ten thousand apartments in the area located closer to the centre, but this kind of land is hardly available at present. According to the authors, such large increases in housing prices already show signs of a price bubble; however, the pandemic situation with subsequent potential lockdowns make it difficult to forecast its further development or deactivation. Importantly, the symptoms of price bubbles are also noticed on other markets [52, 56, 57, 58, 59].

There is no turning back from the digital economy, which is increasingly entering new areas [60]. Digitization is already ubiquitous on the real estate market [61], as in the area of housing prices $[62,63]$, property value estimation $[64,65]$, and ending with virtual real estate agents or virtual tours $[66,67]$. Technological challenges, as well as the issue of quantitative easing (QE) policy recently conducted by some countries, such as Japan, the United States or the European Union (which, according to experts, is contributing to the increase in housing prices [68]), were not at the heart of our research. Which does not exclude that the surveyed managers from our groups did not have such knowledge in this regard [69], which could make their answers more thoughtful.

\section{Conclusion}

Not every imbalance of supply and demand causes a bubble. Polish experience shows that the greatest opportunities occur when there is a large opening of supply and demand scissors, along with the coincidence of various shock factors. Declining production is not able to meet a rapidly growing demand, causing a sharp increase in prices. On most large markets, changes in both of these parameters are quite calm and usually parallel. The identification and measurement of bubbles are the basis for a possible crisis early warning system, which should be run by the central bank or a government forecasting centre. Predictive analytics and constant monitoring of the housing market can make it possible to predict and prevent price bubbles. The demand for information on the housing market situation, including in particular macroeconomic imbalances, led to the development of procedures to detect and warn against price bubbles, in particular within central banks. However, can such procedures be sufficient? The Thucydides Trap, which may refer to Poland and Portugal (and to many other similar countries) 
whose future depends on EU countries, but also to other countries, experiencing growths as well as crises, requires systematic studies on the future with the use of predictive analytics tools, especially in the area of speculative bubbles.

\section{References:}

[1] Bischi, G. I., Gallegati, M., Gardini, L., Leombruni, R., \& Palestrini, A. (2006). Herd behavior and nonfundamental asset price fluctuations in financial markets. Macroeconomic Dynamics, 10(4), 502-528.

[2] Azariadis, C., Kaas, L. (2007). Asset price fluctuations without aggregate shocks. Journal of Economic Theory, 136(1), 126-143.

[3] Wheatley, S., Wehrli, A., \& Sornette, D. (2019). The endo-exo problem in high frequency financial price fluctuations and rejecting criticality. Quantitative Finance, 19(7), 11651178.

[4] Liu, F., Ren, H., Liu, C. (2019). Housing price fluctuations and financial risk transmission: a spatial economic model. Applied Economics, 51(53), 5767-5780.

[5] Schmitt, N., Westerhoff, F. (2021). Pricking asset market bubbles. Finance Research Letters, 38,101441 .

[6] Kindleberger, C. P., Aliber, R. Z. (2005). Manias, Panics, and Crashes. A History of Financial Crises. Hoboken: John Wiley \& Sons, Inc.

[7] Gómez E., Rozo S. (2007) Beyond Bubbles: The role of asset prices in early - warning indicators, Borradores de Economia, 457.

[8] Nuzzo, S., \& Morone, A. (2017). Asset markets in the lab: A literature review. Journal of Behavioral and Experimental Finance, 13, 4250.

[9] Halim, E., Riyanto, Y. E., Roy, N. (2019). Costly information acquisition, social networks, and asset prices: Experimental evidence. The Journal of Finance, 74(4), 1975-2010.

[10] Kalicki, K., Krześniak, A. (2010). Stabilność międzynarodowych rynków aktywów finansowych, w: Stabilność międzynarodowych rynków finansowych. Oficyna Warszawa: Wydawnicza Szkoła Główna Handlowa.

[11] Łaszek, J. (2008). Bańki cenowe na rynkach mieszkaniowych i wybrane metody ich pomiaru. Finansowanie Nieruchomości, 3.

[12] Shi, L., Wang, B., Guo, X., \& Li, H. (2021). A price dynamic equilibrium model with trading volume weights based on a price-volume probability wave differential equation.
International Review of Financial Analysis, 74, 101603.

[13] Garber P. (2000). Famous First Bubbles. MIT Press.

[14] Lind, H. (2008). Price Bubbles on the Housing Market: Concept, theory and indicators. Working Paper, 58.

[15] Kindleberger, C. P. (1999). Szaleństwo, panika, krach. Teoria kryzysów finansowych, Warszawa: WIG PRESS.

[16] Evgenidis, A., \& Malliaris, A. G. (2020). To lean or not to lean against an asset price bubble? Empirical evidence. Economic Inquiry, 58(4), 1958-1976.

[17] Starzeński, O. (2011). Analiza rynków finansowych. Warszawa: C.H. Beck.

[18] Trevillion, E. (2021). Using system dynamics modelling to understand behaviour in UK commercial property markets. Journal of European Real Estate Research.

[19] Trojanek, R. (2008). Wahania cen na rynku mieszkaniowym. Poznań: Wydawnictwo Akademii Ekonomicznej w Poznaniu.

[20] Żelazowski, K. (2007). Zjawisko bańki cenowej $w$ kontekście zmian na polskim rynku mieszkaniowym, Olsztyn: Studia i Materiały Towarzystwa Naukowego Nieruchomości.

[21] Gölgeci, I., Assadinia, S., Kuivalainen, O., Larimo, J. (2019). Emerging-market firms' dynamic capabilities and international performance: The moderating role of institutional development and distance. International Business Review, 28(6), 101593.

[22] Leamer, E. E. (2007). Housing is the Business Cycle. NBER Working Paper Series, 13428.

[23] Waldron, R. (2018). Capitalizing on the state: The political economy of real estate investment trusts and the 'resolution' of the crisis. Geoforum, 90, 206-218.

[24] Friedman M. (1953). Essays in Positive Economics. Chicago: Chicago Press.

[25] Adelino, M., Schoar, A., Severino, F. (2018). The role of housing and mortgage markets in the financial crisis. Annual Review of Financial Economics, 10, 25-41.

[26] Olszewski, K., Gałaszewska, K., Jakubowski, A., Leszczyński, R., Żywiecka, H. (2019). Monitoring and analysis of the risk of the commercial real estate sector in Poland: data sources, methodology and empirical results. Bank i Kredyt, 50(6), 571-604.

[27] Borsuk, M., \& Krzesicki, O. (2020). InSTAIntegrated Stress-testing Approach at NBP: The Past, Present and Future Perspectives. Warszawa: Narodowy Bank Polski. 
[28] Abad-González, J., Gutiérrez-López, C., Salvador, A. (2018). Banking solvency determinants in the EU: a model based on stress tests. Applied Economics Letters, 25(18), 12961300 .

[29] Breuer, T., Summer, M. (2020). Systematic stress tests on public data. Journal of Banking \& Finance, 118, 105886.

[30] Masiukiewicz, P., Dec, P. (2015). Behawioralne aspekty baniek ceowych i sposoby ich dezaktywacji. Ekonomista, 4.

[31] Rantala, J., Rantanen, A., Yllikäinen, M., Holopainen, T. (2021, July). Weakness of Real Estate Collateral Valuation Policy in Changed Financial World. In International Conference on Applied Human Factors and Ergonomics (pp. 405-412). Springer, Cham.

[32] Masiukiewicz, P. (2019). Analityka predykcyjna - teoria i praktyka. Prakseologia $i$ Zarzadzanie, 1.

[33] Waupsh, J. (2016). Bankruption: How Community Banking Can Survive Fintech. New York: Wiley.

[34] Łobejko, S. (2014). Foresight w zarzadzaniu strategicznym, [in:] Rozważania o gospodarce: teoria i praktyka. D. Niedziółka (ed.). Warszawa: CeDeWu.pl.

[35] Lepenioti, K., Bousdekis, A., Apostolou, D., Mentzas, G. (2020). Prescriptive analytics: Literature review and research challenges. International Journal of Information Management, 50, 57-70.

[36] Czerniak, A., Witkowski, B. (2016). Model wczesnego ostrzegania przed bańkami cenowymi na rynku mieszkaniowym. Materiały i Studia, 326.

[37] Masiukiewicz, P., Dec, P. (2013). Czynniki kreacji bańki cenowej na rynku nieruchomości. Annales Universitatis Mariae Curie-Skłodowska Sectio H Oeconomia, UMCS Lublin, XLVII, 3.

[38] Gwardecki, M. (2021). Ceny mieszkań 2021 jakie prognozy? Retrieved from: www.enerad.pl/aktualnosci (2021.06.22).

[39] Taleb, N.N. (2007). Black swans and the domains of statistics. The American Statistician, 61(3), 198-200.

[40] Van der Wal, Z. (2020). Being a public manager in times of crisis: The art of managing stakeholders, political masters, and collaborative networks. Public Administration Review, 80(5), 759-764.

[41] Ehrig, T., Katsikopoulos, K., Jost, J., Gigerenzer, G. (2021). An exploratory study of heuristics for anticipating prices. Management Decision.
[42] Brzezicka, J. (2021). Towards a typology of housing price bubbles: a literature review. Housing, Theory and Society, 38(3), 320-342.

[43] Oh, S., Ku, H., Jun, D. (2021). A comparative analysis of housing prices in different cities using the Black-Scholes and Jump Diffusion models. Finance Research Letters, 102241.

[44] Łaszek J. Augustyniak, H., Widłak, M. (2010). Cykle na warszawskim rynku nieruchomości mieszkaniowych. Finansowanie Nieruchomości, 1.

[45] Gupta, R., Sheng, X., Ji, Q. (2021). Movements in real estate uncertainty in the United States: the role of oil shocks. Applied Economics Letters, 28(13), 1059-1065.

[46] Malpezzi, S., Wachter, S. M. (2004). The Role of Speculation in Real Estate Cycles, University of Pennsylvania, May.

[47] Kloppenburg, W. (2021). Are Real Estate Prices Evolving into an Asset Price Bubble? Acta VŠFS-ekonomické studie a analýzy, 15(1), 36-48.

[48] Wang, J., Xia, B., Qiao, H. (2021). Time- varying impact of housing price fluctuations on banking financial risk. Managerial and Decision Economics.

[49] Hagemann, D., Wohlmann, M. (2019). An early warning system to identify house price bubbles. Journal of European Real Estate Research.

[50] Rodrigue J.P. The Geography of Transport Systems, 5th ed. Routledge, New York, 2020.

[51] Bordalo, P., Gennaioli, N., Kwon, S. Y., Shleifer, A. (2021). Diagnostic bubbles. Journal of Financial Economics, 141(3), 1060-1077.

[52] Álvarez-Román, L., García-Posada, M. (2021). Are house prices overvalued in Spain? A regional approach. Economic Modelling, 99, 105499.

[53] Stiglitz, J. E. (2010). Freefall: America, free markets, and the sinking of the world economy. WW Norton \& Company.

[54] Bago, J. L., Rherrad, I., Akakpo, K., Ouédraogo, E. (2021). Real Estate Bubbles and Contagion: Evidence from Selected European Countries. Review of Economic Analysis, 13(1).

[55] Sarniewicz M. Ceny mieszkań w Polsce coraz wyższe. Prognozy 2021, rynek wtórny i pierwotny. Retrieved from: www.muratorplus.pl/ceny-mieszkan-w-Polsce (2021.05.20).

[56] Anundsen, A. K. (2021). House price bubbles in Nordic countries? Nordic Economic Policy Review, 4. 
[57] Alter, A., Mahoney, E. M. (2021). Local houseprice vulnerability: Evidence from the US and Canada. Journal of Housing Economics, 101791.

[58] Hejlová, H., Holub, L., Plašil, M. (2021). Calibration of Borrower-based Macroprudential Measures for Mortgage Exposures: Rigorous Approach and Its Application to the Czech Republic. Prague Economic Papers, 30(3), 316335.

[59] Cuestas, J. C., Kukk, M., Levenko, N. (2021). Misalignments in house prices and economic growth in Europe. Eesti Pank.

[60] Shkarlet, S., Dubyna, M., Shtyrkhun, K., \& Verbivska, L. (2020). Transformation of the Paradigm of the Economic Entities Development in Digital Economy. WSEAS Transactions on Environment and Development, $16,413-422$.

[61] Vladimirova, I., Kallaur, G., \& Bareshenkova, K. (2018). Digital methods of real estate asset lifecycle management. Baltic Journal of Real Estate Economics and Construction Management, 6(1), 165-174.

[62] Rampini, L., \& Cecconi, F. R. (2021). Artificial intelligence algorithms to predict Italian real estate market prices. Journal of Property Investment \& Finance.

[63] Pinter, G., Mosavi, A., \& Felde, I. (2020). Artificial intelligence for modeling real estate price using call detail records and hybrid machine learning approach. Entropy, 22(12), 1421.

[64] Ho, W. K., Tang, B. S., \& Wong, S. W. (2021). Predicting property prices with machine learning algorithms. Journal of Property Research, 38(1), 48-70.

[65] Huang, Y. (2019). Predicting home value in California, United States via machine learning modeling. Statistics, Optimization \& Information Computing, 7(1), 66-74.

[66] Ullah, F., Sepasgozar, S. M., \& Wang, C. (2018). A systematic review of smart real estate technology: Drivers of, and barriers to, the use of digital disruptive technologies and online platforms. Sustainability, 10(9), 3142.

[67] Yu, W., Ma, Z., Pant, G., \& Hu, J. (2021). The Effect of Virtual Tours on House Price and Time on Market. Journal of Real Estate Literature, 28(2), 133-149.

[68] Miyakoshi, T., Li, K. W., Shimada, J., \& Tsukuda, Y. (2020). The impact of quantitative easing and carry trade on the real estate market in Hong Kong. International Review of Economics \& Finance, 69, 958-976.
[69] Bartkiewicz, P. (2018). The impact of quantitative easing on emerging markets literature review. Financial Internet Quarterly'e-Finanse, 14(4).

\section{Creative Commons Attribution License 4.0 (Attribution 4.0 International, CC BY 4.0)}

This article is published under the terms of the Creative Commons Attribution License 4.0 https://creativecommons.org/licenses/by/4.0/deed.en US 